\title{
Trilobites—a visual journey
}

David Penney

Acta Palaeontologica Polonica 59 (3), 2014: 662-662 doi: http://dx.doi.org/10.4202/app.2014.1002

Riccardo Levi-Setti 2014. The Trilobite Book: A Visual Journey. 288 pp. The University of Chicago Press. Hardcover. ISBN: 978-0-226-12441-4. Price \$45.00/£31.50.

David Penney [david.penney@manchester.ac.uk], Faulty of Life Sciences, University of Manchester, Oxford Road, Manchester M13 9PL, UK.

This is an open-access article distributed under the terms of the Creative Commons Attribution License (for details please see creativecommons.org), which permits unrestricted use, distribution, and reproduction in any medium, provided the original author and source are credited.

FoF 